University of Rhode Island

DigitalCommons@URI

The Rhode Island Current Conditions Index

Economics

$11-2005$

\title{
Rhode Island Current Conditions Index - November 2005
}

Leonard Lardaro

University of Rhode Island, lardaro@uri.edu

Follow this and additional works at: https://digitalcommons.uri.edu/ricci

Part of the Econometrics Commons

Terms of Use

All rights reserved under copyright.

\section{Recommended Citation}

Lardaro, Leonard, "Rhode Island Current Conditions Index -- November 2005" (2005). The Rhode Island Current Conditions Index. Paper 96.

https://digitalcommons.uri.edu/ricci/96

This Article is brought to you for free and open access by the Economics at DigitalCommons@URI. It has been accepted for inclusion in The Rhode Island Current Conditions Index by an authorized administrator of DigitalCommons@URI.For more information, please contact digitalcommons-group@uri.edu. 


\section{GURRENT D The}
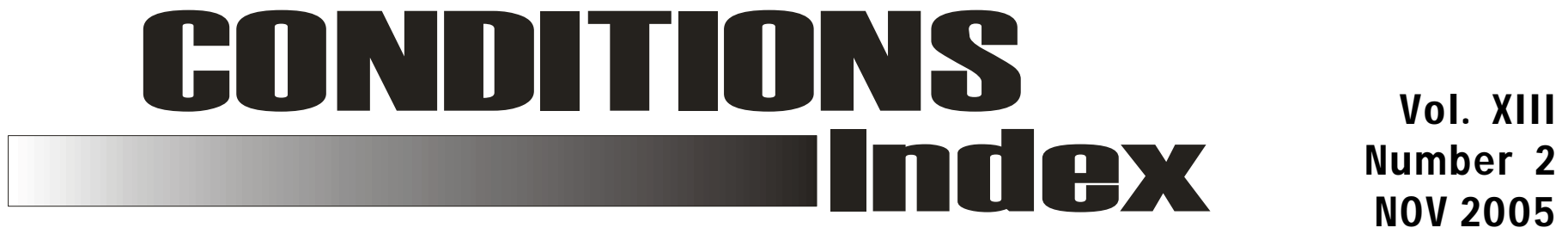

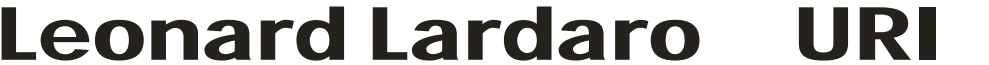

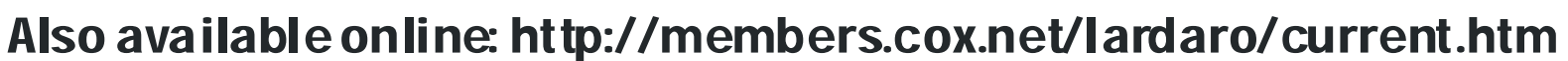

The early fourth quarter doldrums we witnessed in October were erased somewhat as the Current Conditions Index moved from its neutral value of 50 last month back to its "first gear" value of 58 in November. While Rhode Island's economy continues to grow, it does so without a great deal of momentum. The underlying story should be all too familiar by now: the forces generating positive momentum continue to be offset by negative factors. As a result, Rhode Island's economy continues to lag the pace of national economic activity.

That's not to say that there was no good news in November. Rhode Island's Labor Force, New Claims, and Benefit Exhaustions all turned in very strong performances. The onemonth decline in labor demand that we witnessed in October also ended. And Retail Sales continued to grow at a healthy pace, in spite of weak Consumer Sentiment.

Retail Sales growth $(+2.1 \%)$ was below its longer-term average, reflective of a modest holiday shopping season. Keep in mind that this measure, which is derived from sales tax

\begin{tabular}{lr}
\multicolumn{2}{c}{ CCI I ndicators - \% Change } \\
Government Employment & -0.3 \\
US Consumer Sentiment & -12.1 \\
Single-Unit Permits & -17.9 \\
Retail Sales & 2.1 Y \\
Help Wanted Advertising & 0.7 Y \\
Priv. Serv-Prod Employment & $2.2 \mathbf{Y}$ \\
Total Manufacturing Hours & -5.3 \\
Manufacturing Wage & $1.7 \mathbf{~ Y}$ \\
Labor Force & $3.4 \mathbf{Y}$ \\
Benefit Exhaustions & $-21.8 \mathbf{Y}$ \\
New Claims & $-15.7 \mathbf{Y}$ \\
Unemployment Rate & 8.3 \\
\multicolumn{1}{c}{ Y = I mproved Value } &
\end{tabular}

revenue, excludes clothing purchases, which have done well of late. So, the November rate understates the growth of total Retail Sales somewhat. November also witnessed another sharp drop in US Consumer Sentiment (12.1 percent), its eleventh decline since last November.

The demand for labor, in terms of Help Wanted Advertising, rose in November by 0.7 percent, ending its one-month decline. Along with this improvement, there were dramatic declines in both Benefit Exhaustions, which reflect long-term unemployment $(-21.8 \%)$ and New Claims, which mirrors layoffs $(-15.7 \%)$. For Benefit Exhaustions, this was its best performance since June. The decline in New Claims was its sharpest in over a year. Hopefully, the trend of monthly improvements in both of these indicators has resumed.

November saw yet another dramatic rise in our Labor Force $(+3.4 \%)$, but the "comp" from last November was weak. At any rate, our Labor Force has now risen every month since March, reversing last year's string of persistent declines. In view this continued Labor Force growth, the rise in our Unemployment Rate from 4.8 percent last November to 5.2 percent this November is less problematic than it appears.

Government Employment fell again in November (by $0.3 \%$ ), keeping it below 66,000. As this was occurring, the rate of growth in Private Service-Producing Employment accelerated back to 2.2 percent, which has been its highest rate of growth in the last year. Weakness in our goodsproducing sector continued. Total Manufacturing Hours fell by 5.3 percent, its most rapid rate of decline since August. Yet in spite of this decline, the Manufacturing Wage grew by 1.7 percent in November, which matches its most rapid rate of growth in the last year. Unfortunately, new home construction, in terms of Single-Unit Permits, fell by 17.9 percent in November, continuing the roller coaster ride of monthly changes.

November's economic performance provided the uptick in the $\mathrm{CCl}$ that I anticipated in last month's report. While the pace of economic activity in Rhode Island is not as rapid as we would like, I believe that our performance is a bit stronger than the 58 indicated by this month's $\mathrm{CCl}$. Let's be thankful the winter thus far has been relatively mild and that energy prices have remained at levels that have not threatened the pace of national economic activity.

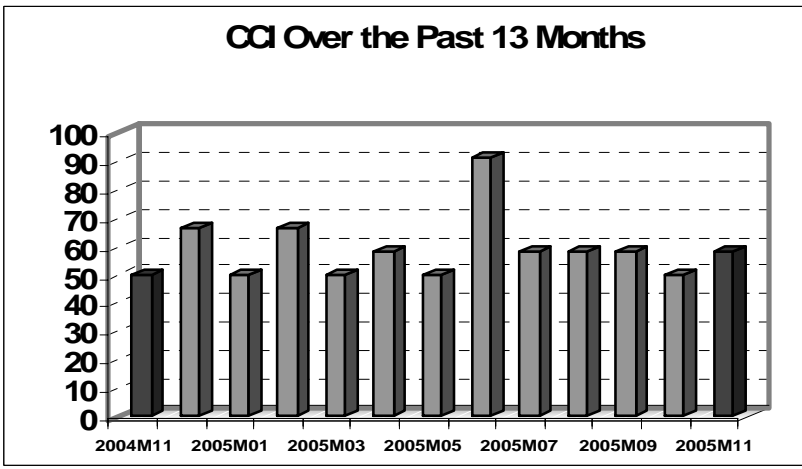

\begin{tabular}{|c|c|c|c|c|c|c|c|c|c|c|c|c|}
\hline & Jan & Feb & Mar & Apr & May & $J$ un & Jul & Aug & Sep & Oct & Nov & Dec \\
\hline 2004 & 67 & 67 & 58 & 67 & 58 & 58 & 67 & 67 & 67 & 58 & 50 & 67 \\
\hline 2005 & 50 & 67 & 58 & 58 & 50 & 92 & 58 & 58 & 58 & 50 & 58 & \\
\hline
\end{tabular}

